\title{
ANALISIS KEMAMPUAN REPRESENTASI MATEMATIS PESERTA DIDIK PADA MATERI PROGRAM LINEAR
}

\author{
Eunike Ester Mataheru ${ }^{1 *}$, Tanwey Gerson Ratumanan², Carolina Selfisina $\mathrm{Ayal}^{3}$ \\ ${ }^{1,2,3}$ Prodi Magister Pendidikan Matematika, Pascasarjana, Universitas Pattimura \\ Jalan Ir. M. Putuhena, Ambon, Indonesia \\ e-mail: ${ }^{1}$ emataheru@yahoo.com; \\ Submitted: September 17,2021 \\ Revised: October 21, 2021 \\ Accepted: December 14, 2021 \\ corresponding author*
}

\begin{abstract}
Abstrak
Kemampuan representasi matematis adalah kemampuan menyajikan kembali notasi, simbol, tabel, gambar, grafik, diagram, persamaan atau ekspresi matematis lainnya ke dalam bentuk lain yang dimiliki oleh peserta didik dalam upaya mencari solusi dari suatu masalah yang dihadapi. Oleh karena itu, hendaknya guru memberikan kesempatan yang cukup bagi peserta didik untuk dapat melatih dan mengembangkan kemampuan representasi matematis sebagai bagian yang penting dalam menyelesaikan masalah yang diberikan. Pada kenyataannya kemampuan representasi matematis pada peserta didik masih saja rendah. Peserta didik masih sukar dalam menyelesaikan masalah matematik yang berkaitan pada aspek indikator verbal, indikator gambar, dan indiator simbol, hal ini bisa ditemukan pada materi program linear. Selain itu, materi program linear pun seringkali dianggap sebagai materi yang sulit oleh peserta didik dalam pembelajaran matematika. Penelitian ini bertujuan untuk mendeskripsikan kemampuan representasi matematis peserta didik meliputi representasi simbol, representasi gambar, representasi verbal pada materi program linear di kelas XI SMA Negeri 3 Ambon. Jenis Penelitian yang digunakan adalah penelitian kombinasi (mixed methods). Penelitian dilakukan di SMA Negeri 3 Ambon dengan jumlah subjek penelitian 36 orang dari kelas XI MIPA 4 dan subjek yang dipilih untuk diwawancarai yaitu berdasarkan hasil tes kemampuan representasi matematis. Dari hasil tes kemampuan representasi matematis pada materi program linear, peserta didik dikelompokan berdasarkan kategori sangat tinggi, tinggi, sedang, rendah, dan sangat rendah. Diambil subjek yang diwawancarai yaitu 1 peserta didik dengan kategori sangat tinggi, 1 peserta didik dengan kategori rendah, dan 1 peserta didik dengan kategori sangat rendah. Materi program linear diberikan untuk melihat kemampuan representasi matematis peserta didik. Persentase terbesar hasil tes peserta didik berada pada kategori sangat rendah. Berdasarkan hasil tes menunjukkan bahwa kemampuan representasi matematis peserta didik pada representasi simbol lebih tinggi dari representasi gambar dan representasi verbal. Sedangkan dari ketiga subjek yang diwawancarai ditemukan bahwa subjek cenderung memenuhi indikator kemampuan representasi simbol dibandingkan indikator kemampuan representasi gambar dan representasi verbal.
\end{abstract}

Kata Kunci: kemampuan representasi matematis, program linear

\section{ANALYSIS OF STUDENTS' MATHEMATICAL REPRESENTATION ABILITIES ON LINEAR PROGRAMING MATERIAL}

\begin{abstract}
Mathematical representation ability is the ability to present notations, symbols, tables, pictures, graphs, diagrams, equations, or other mathematical expressions into other forms possessed by students to find solutions to a problem at hand. Therefore, teachers should provide sufficient opportunities for students to be able to train and develop mathematical representation skills as an important part of solving the problems given. The mathematical representation ability of students is still low. Students still find it difficult to solve mathematical problems related to aspects of verbal indicators, picture indicators, and symbol indicators. This can be found in linear programming material. Also, linear programming material is often considered difficult material by students in learning mathematics. This study aims to describe students' mathematical representation abilities including symbol representation, image representation, verbal representation on linear programming material in class XI SMA Negeri 3 Ambon. The type of research used is combination research (mixed methods). The research was conducted at SMA Negeri 3 Ambon with 36 research subjects from class XI MIPA 4 and the subjects chosen to be interviewed were based on the results of the mathematical representation ability test. From the results of the mathematical representation ability test on linear programming material, students are grouped based on the very high, high, medium, low, and very
\end{abstract}

Copyright $(\odot$ Authors. This is an open access article distributed under the Attribution-NonCommercialShareAlike 4.0 International (CC BY-NC-SA 4.0), which permits unrestricted use, distribution, and reproduction in any medium, provided the original work is properly cited. 
low categories. The subjects interviewed were 1 student with a very high category; 1 student with a low category, and 1 student with a very low category. Linear programming material is given to help students improve mathematical representation abilities. The largest percentage of students' test results are in the very low category. Based on the test results, it shows that the mathematical representation ability of students on symbol representation is higher than image representation and verbal representation. Meanwhile, from the three subjects interviewed, it was found that subjects tended to fulfill the indicator of symbol representation ability compared to the indicators of image representation and verbal representation.

Keywords: mathematical representation ability, linear programming

\section{Pendahuluan}

Berpikir matematis termasuk dalam salah satu tujuan pembelajaran matematika di sekolah. Oleh karena itu, pengembangan kemampuan berpikir matematis sangat diperlukan agar peserta didik lebih memahami konsep yang dipelajari, dan dapat menerapkannya dalam berbagai situasi. Dalam kurikulum 2013 peserta didik diharapkan dapat memiliki keterampilan dan kemampuan yang sesuai dengan kompetensi inti dalam pembelajaran matematika (Peraturan Menteri Pendidikan dan Kebudayaan Republik Indonesia No. 21 Tahun 2016 Tentang Standar Isi Pendidikan Dasar Dan Menengah, 2016). Hal ini sejalan dengan pernyataan National Council of Teachers of Mathematics (Keller et al., 2001) bahwa salah satu kemampuan yang harus dimiliki oleh peserta didik dalam mempelajari matematika yaitu kemampuan representasi.

Kemampuan representasi sangat penting dimiliki oleh peserta didik karena mampu mempermudah peserta didik dalam mempelajari matematika, sebagaimana pernyataan NCTM Triono (2017) bahwa representasi merupakan pusat dari pembelajaran matematika. Melalui membuat, membandingkan dan menggunakan representasi, peserta didik dapat mengembangkan dan memperdalam pemahaman mereka akan konsep dan hubungan antarkonsep matematika yang telah mereka miliki. Kemampuan representasi yang dikuasai dengan baik akan membantu peserta didik dalam mempelajari matematika. Hal ini diperkuat juga oleh pendapat Lestari (2012) yang mengemukakan bahwa salah satu cara terbaik membantu peserta didik memahami matematika adalah melalui representasi matematis, yaitu dengan mendorong peserta didik untuk menemukan atau membuat representasi sebagai alat berpikir dalam mengkomunikasikan gagasan matematika. Tetapi pada kenyataannya, kemampuan representasi peserta didik dalam indikator visual, verbal dan simbol masih rendah (Triono, 2017).

Representasi termasuk salah satu aspek dalam penilaian literasi matematika, karena indikator dalam kemampuan literasi adalah representasi (Zakkia et al., 2019). Berdasarkan hasil PISA tahun 2015, Indonesia berada di peringkat 62 dari 70 Negara dengan skor 386 pada literasi matematika (OECD, 2015). Sedangkan untuk Hasil PISA tahun 2018 menunjukkan bahwa peringkat PISA Indonesia tahun 2018 turun apabila dibandingkan dengan Hasil PISA tahun 2015, untuk kategori matematika, Indonesia berada di peringkat 7 dari bawah (73) dengan skor rata-rata 379 (Tohir, 2019).

Hasil TIMSS di tahun 2011 juga menunjukkan bahwa Indonesia berada pada peringkat 38 dari 42 negara dengan kategori skor rendah yaitu 386 (IEA, 2012) dan hasil terbaru, yaitu TIMSS 2015 Indonesia berada di peringkat 44 dari 49 negara (Hadi \& Novaliyosi, 2019).

Hasil studi PISA dan TIMSS tersebut menunjukan bahwa kualitas pembelajaran matematika di berbagai sekolah masih rendah, demikian pula dengan hasil belajar peserta didik di berbagai sekolah juga masih rendah. Karena rendahnya hasil belajar salah satunya dipengaruhi oleh rendahnya kemampuan representasi matematis (Thoriqul \& Mustangin, 2020), maka dapat dikatakan juga bahwa kemampuan representasi matematis peserta didik dalam pembelajaran matematika diberbagai sekolah pula masih rendah. Hal ini dapat disebabkan karena peserta didik masih mengalami kesulitan dalam menggunakan representasi pada pembelajaran matematika. Keadaan ini dipengaruhi oleh beberapa faktor, diantaranya keterbatasan pengetahuan guru, kebiasaan peserta didik belajar di kelas dengan cara konvensional, dan peserta didik yang cenderung malas dalam mengidentifikasi suatu masalah (Muhamad, 2016). Kemudian temuan Amri (Mandur, dkk, 2013) juga menyatakan bahwa peserta didik kurang diberikan kesempatan oleh guru untuk menghadirkan dan menggunakan kemampuan representasi matematisnya, sehingga peserta didik cenderung mengikuti proses penyelesaian soal yang dibuat gurunya. Hal ini diperkuat oleh pendapat Setyabudhi (Handayani, 2015) yang menyatakan bahwa pembelajaran matematika di Indonesia 
memang masih menekankan pada menghafal rumus dan menghitung, bahkan guru pun sewenang-wenang dengan keyakinannya pada rumus-rumus atau pengetahuan matematika yang sudah ada, sehingga peserta didik juga tidak diberikan kesempatan untuk menggunakan pemikirannya dalam memunculkan ide-idenya sendiri.

Kesulitan peserta didik dalam menggunakan kemampuan representasinya untuk menyelesaikan masalah pada pembelajaran matematika dapat ditemukan pada materi program linear. Hal ini selaras dengan pernyataan Izah, dkk (2018) yang mengungkapkan bahwa tingkat kemampuan menyelesaikan masalah program linear yang dimiliki peserta didik masih rendah, sebab masih banyak peserta didik yang mengalami kesulitan dalam menyelesaikan soal-soal program linear terutama dalam memodelkan soal cerita kedalam kalimat matematika dan menggambarkannya kedalam bentuk grafik. Selain itu, Fikri et al (2017) pula menyatakan bahwa salah satu materi yang sering kali dianggap sulit oleh peserta didik di SMA/MA adalah program linear, dikarenakan materi tersebut berkaitan dengan pemodelan yang membutuhkan kemampuan berpikir logis untuk memahami soal cerita, kemampuan bernalar untuk memodelkan dan membiasakan peserta didik dalam mengerjakan soal agar mampu menyelesaikan masalah.

Dari observasi awal yang dilakukan di SMA Negeri 3 Ambon, ditemui bahwa peserta didik belum dapat menggunakan kemampuan representasinya, khususnya yang berkaitan dengan representasi simbol dan representasi gambar, yakni dalam membuat model matematika dan menggambar grafik garis selidik dalam menyelesaikan soal-soal program linear. Sehingga, rumusan masalah dalam penelitian ini adalah bagaimana kemampuan representasi matematis peserta didik meliputi representasi simbol, representasi gambar, dan representasi verbal pada materi program linear?

\section{Metode Penelitian}

Jenis Penelitian yang digunakan adalah penelitian kombinasi (mixed methods). Menurut Sugiyono (2011) penelitian kombinasi (mixed methods) adalah suatu jenis penelitian yang mengkombinasikan atau menggabungkan antara jenis penelitian kuantitatif dan jenis penelitian kualitatif untuk digunakan secara bersama-sama dalam suatu penelitian sehingga diperoleh data yang lebih lengkap, meyakinkan, teruji, dan rasional. Tahap pertama dalam penelitian ini adalah mengumpulkan dan menganalisis data kuantitatif kemudian diikuti dengan mengumpulkan dan menganalisis data kualitatif yang dibangun berdasarkan hasil awal kuantitatif.

Penelitian ini dilaksanakan di SMA Negeri 3 Ambon pada tanggal 23 Agustus sampai dengan 23 September 2019. Sumber data dalam penelitian ini adalah peserta didik kelas XI MIPA SMA Negeri 3 Ambon dengan jumlah subjek penelitian 36 orang dari kelas XI MIPA 4 dan subjek yang dipilih untuk diwawancarai yaitu berdasarkan hasil tes kemampuan representasi matematis pada materi program linear yang telah dikelompokan berdasarkan kategori sangat tinggi, tinggi, sedang, rendah serta pendapat guru terhadap subjek, yaitu peserta didik yang aktif saat proses belajar mengajar dan mampu berkomunikasi.

Instrumen yang digunakan adalah instrumen tes kemampuan representasi matematis dan pedoman wawancara. Soal tes disusun dalam bentuk uraian untuk mengukur tingkat kemampuan representasi matematis peserta didik pada materi Program Linear yang diadaptasi dari buku Three in One Matematika IPA untuk SMA/MA Kelas XII terbitan Erlangga tahun 2013 (Sukino, 2013) dan telah divalidasi oleh dua orang dosen Pendidikan Matematika Universitas Pattimura dan tiga guru matematika SMA Negeri 3 Ambon.

Hasil validasi menunjukkan bahwa instrumen tes kemampuan representasi matematis sudah valid dan siap digunakan untuk penelitian. Sedangkan pedoman wawancara digunakan sebagai teknik pendukung di samping tes untuk memperoleh gambaran tentang kemampuan representasi matematis peserta didik, meliputi representasi simbol, representasi gambar, dan repsesentasi verbal. Selain itu, pedoman wawancara juga digunakan dengan tujuan untuk mencocokkan antara jawaban di lembar jawab dengan yang sebenarnya dipahami.

Teknik analisis data dalam penelitian ini adalah analisis data kuantitatif dan analisis data kualitatif. Data kuantitatif berupa hasil tes kemampuan representasi matematis yang dianalisis menggunakan statistik deskriptif dengan menentukan ukuran data seperti nilai rata-rata (mean), nilai tengah (median), dan nilai modus serta menentukan ukuran variabilitas data yaitu jarak (range). Dari hasil tes, kemampuan peserta didik kemudian di kategorikan berdasarkan acuan PAP pada semua level, peneliti mengkategorikan data menjadi lima kategori mutlak, yaitu: sangat tinggi; tinggi; sedang; rendah; dan sangat rendah dengan interval yang diterjemahkan ke dalam kategori sebagai berikut: 
Tabel 1. Penilaian acuan patoka

\begin{tabular}{ll}
\hline Interval & Kategori \\
\hline $\boldsymbol{x} \geq 90$ & Sangat Tinggi \\
$75 \leq \boldsymbol{x}<90$ & Tinggi \\
$60 \leq \boldsymbol{x}<75$ & Sedang \\
$40 \leq \boldsymbol{x}<60$ & Rendah \\
$\boldsymbol{x}<40$ & Sangat Rendah \\
\hline Sumber: (Ratumanan \&
\end{tabular}

Sedangkan analisis data kualitatif menggunakan teknik analisis data menurut Miles dan Huberman (Emzir, 2014), yaitu reduksi data, penyajian data, dan penarikan kesimpulan.

\section{Hasil dan Pembahasan}

\section{Kemampuan Representasi Matematis Peserta Didik Keseluruhan}

Berdasarkan hasil tes kemampuan representasi peserta didik diperoleh nilai rata-rata peserta didik sebesar 17.61. Jika hasil tes peserta didik dikelaskan dalam kategori sangat tinggi, tinggi, sedang, rendah dan sangat rendah, akan diperoleh frekuensi dan persentase sebagai berikut:

Tabel 2. Klasifikasi hasil tes peserta didik Kelas XI MIPA 4 SMA N 3 Ambon

\begin{tabular}{cccc}
\hline Kategori & Interval & Frekuensi & $\begin{array}{c}\text { Persentase } \\
(\%)\end{array}$ \\
\hline Sangat & $x \geq 90$ & 1 & 2.78 \\
Tinggi & & & \\
Tinggi & $75 \leq x<90$ & 0 & 0 \\
Sedang & $60 \leq x<75$ & 0 & 0 \\
Rendah & $40 \leq x<60$ & 1 & 2.78 \\
Sangat & $x<40$ & 34 & 94.44 \\
Rendah & Total & 36 & 100 \\
\hline
\end{tabular}

Berdasarkan tabel di atas, maka dapat diketahui bahwa 1 peserta didik (2.78\%) berada pada kategori sangat tinggi, 1 peserta didik $(2.78 \%)$ berada pada kategori rendah dan 34 peserta didik (94.44\%) berada pada kategori sangat rendah, sedangkan tidak terdapat peserta didik yang berada pada kategori tinggi dan kategori sedang. Jadi, dapat disimpulkan bahwa persentase terbesar hasil tes kemampuan representasi matematis peserta didik keseluruhan berada pada kategori sangat rendah.

\section{Kemampuan Representasi Matematis Peserta Didik Meliputi Representasi Simbol, Verbal, dan Gambar}

Selain berdasarkan jumlah frekuensi keseluruhan dapat juga dibentuk tabel dan diagram berdasarkan nilai rata-rata tiap indikator representasi matematis. Berikut ini adalah tabel nilai rata-rata tiap representasi matematis:

Tabel 3. Nilai rata-rata kemampuan representasi simbol, gambar, dan verbal

\begin{tabular}{clccc}
\hline \multirow{2}{*}{ No. } & Representasi & $\begin{array}{c}\text { Skor Maks/ } \\
\text { Ideal }\end{array}$ & $\overline{\boldsymbol{X}}$ & $\%$ \\
\cline { 4 - 5 } 1. & Simbol & 6 & 2.14 & 35.65 \\
2. & Gambar & 9 & 1.03 & 11.42 \\
3. & Verbal & 9 & 0.33 & 3.70 \\
\hline
\end{tabular}

Berdasarkan Tabel 3 diketahui bahwa representasi simbol (Symbolic Representation) memiliki skor ideal 6 karena memiliki dua soal, sedangkan representasi Gambar (Pictorial Representation) dan representasi Verbal (Verbal Representation) memiliki skor ideal 9 karena memiliki tiga soal. Representasi simbol, gambar, dan verbal pada setiap soal memiliki skor maksimum 3. Hasil analisis data kuantitatif menunjukan nilai tertinggi yaitu pada representasi simbol (Symbolic Representation) dengan skor rata-rata 2.14 dari skor maksimal 6 (35.65\%), menandakan bahwa sebagian peserta didik dinyatakan cukup mampu menyelesaikan permasalahan matematika dengan menggunakan model matematika. Sedangkan nilai terendah yaitu pada representasi verbal (Verbal Representation) dengan skor rata-rata 0.33 dari skor maksimal 9 (3.70\%), dapat dikatakan kemampuan peserta didik dalam menyelesaikan permasalahan matematika dengan menggunakan representasi verbal (Verbal Representation) tidak sebaik menggunakan representasi simbol (Symbolic Representation).

Kemampuan peserta didik dalam menyelesaikan permasalahan matematika dengan menggunakan representasi gambar (Pictorial Representation) juga tidak sebaik menggunakan representasi simbol (Symbolic Representation). Selisih skor rata-rata tertinggi dan terendah yaitu pada representasi simbol (Symbolic Representation) dan pada representasi verbal (Verbal Representation) sebesar 31.95. Berdasarkan Penilaian Acuan Patokan pada Tabel 1, skor rata-rata masing-masing representasi matematis pada Tabel 3, ketiganya termasuk dalam kategori sangat rendah.

Dari Tabel 3, dapat juga disajikan dalam bentuk diagram batang berikut ini: 




Gambar 1. Nilai rata-rata representasi simbol, gambar, dan verbal

Dari Gambar 1, terlihat bahwa ketiga representasi tersebut memiliki skor rata-rata yang jauh berbeda. Skor rata-rata representasi simbol lebih besar dari skor rata-rata representasi gambar dan representasi verbal. Artinya peserta didik cukup mampu menyelesaikan permasalahan matematika dengan mengubah permasalahan matematika menjadi bentuk simbol-simbol dan membuat model matematikanya.

Dari Tabel 2, maka peserta didik yang dipilih untuk diwawancarai yaitu 1 peserta didik dengan kategori sangat tinggi, 1 peserta didik dengan kategori rendah, dan 1 peserta didik dari 34 peserta didik dengan kategori sangat rendah. Masing-masing peserta didik tersebut antara lain; NPAS dengan kategori sangat tinggi, DPRS dengan kategori rendah, dan NPS dengan kategori sangat rendah.

Soal yang digunakan dalam penelitian meliputi tiga indikator kemampuan representasi matematis yang mengacu pada indikator representasi menurut Villegas (Castellanos et al., 2009), yakni menyelesaikan masalah dengan membuat model ekspresi matematis, membuat gambar atau grafik untuk menyelesaikan masalah yang diberikan dan menjawab soal dengan menggunakan kata-kata atau teks tertulis, seperti berikut ini:

1. Tanah seluas $10.000 \mathrm{~m}^{2}$ akan dibangun rumah tipe $A$ dan tipe $B$. Untuk rumah tipe $A$ dan tipe $B$ diperlukan tanah seluas $100 \mathrm{~m}^{2}$ dan $75 \mathrm{~m}^{2}$. Jumlah rumah tipe $\mathrm{A}$ dan tipe $\mathrm{B}$ yang dibangun paling banyak adalah 125 unit. Keuntungan rumah tipe $A$ adalah Rp 6.000.000,00/unit dan tipe $B$ adalah $\mathrm{Rp}$ 4.000.000,00/unit. Buatlah model matematikanya dan tentukanlah keuntungan maksimum yang dapat diperoleh dari penjualan rumah tersebut!

2. Telah dibentuk model matematika dari sebuah masalah, yaitu:

$$
\begin{aligned}
& \left\{\begin{array} { l } 
{ 1 0 x + 2 0 y \leq 2 0 0 } \\
{ 1 5 x + 5 y \leq 1 0 0 }
\end{array} \text { atau } \left\{\begin{array}{l}
x+2 y \leq 20 \\
3 x+y \leq 20
\end{array}\right.\right. \\
& \left\{\begin{array}{l}
x \geq 0 \\
y \geq 0
\end{array}\right.
\end{aligned}
$$

\section{Dengan: $x=$ Rangkain bunga I}

$$
y=\text { Rangkaian bunga } I I
$$

Fungsi tujuan: Memaksimumkan $Z(x, y)=2 x+y$ (dalam ratusan ribu).

Dari uraian di atas, dengan menggunakan garis selidik, tentukanlah berapa banyak rangkaian bunga I dan II yang seharusnya dijual agar penghasilan toko bunga tersebut maksimum, serta interpretasikanlah penyelesaian yang ditemukan secara kontekstual!

3. Seorang anak diharuskan makan dua jenis tablet setiap hari. Tablet pertama mengandung 5 unit vitamin $\mathrm{A}$ dan 3 unit vitamin $\mathrm{B}$, sedangkan tablet kedua mengandung 10 unit vitamin $\mathrm{A}$ dan 1 unit vitamin B. Anak itu memerlukan 20 unit vitamin A dan 5 unit vitamin B dalam sehari. Jika harga tablet pertama Rp 4.000,00/ butir dan tablet kedua $\mathrm{Rp}$ $8.000,00 /$ butir, serta pengeluaran diusahakan seminal mungkin. Buatlah model matematikanya dan tentukanlah pengeluaran minimum dari pembelian tablet per hari!

Hasil wawancara ketiga subjek berdasarkan instrumen tes di atas adalah sebagai berikut.

\section{Responden: NPAS (Soal Nomor 1)}

Hasil wawancara subjek NPAS (kategori sangat tinggi) terkait representasi simbol untuk soal nomor 1

\begin{tabular}{|l|l|c|c|}
\hline TIPE RUMAH & LUAS TANAH & EANYAK RUMAH & KEUNTUNGAN \\
\hline TIPE A & $100 \mathrm{~m}^{2}$ & $x$ & 6.000 .000 \\
\hline TIPE B & $75 \mathrm{~m}^{2}$ & $y$ & 9.000 .000 \\
\hline TERSEDIA & $10.000 \mathrm{~m}^{2}$ & 125 & - \\
\hline Misalkan: $x=$ Banyak numah tipe A \\
$y=$ Banyak rumah tipe is
\end{tabular}

Gambar 2. Tabel masalah subjek NPAS untuk soal nomor 1

P01 : Bagaimana cara kamu mengubah masalah program linear yang diberikan ke dalam bentuk tabel masalah sesuai dengan penyelesaianmu?

NPAS01 : Iya karena di soalnya diketahui tipe rumahnya itu tipe A dan tipe B, sehingga pada kolom pertama ditulis tipe rumah, kemudian luas tanah untuk rumah tipe $\mathrm{A}$ itu $100 \mathrm{~m}^{2}$ dan tipe $\mathrm{B}$ itu $75 \mathrm{~m}^{2}$, sedangkan luas tanah yang tersedia untuk rumah tipe A dan tipe B itu $10.000 \mathrm{~m}^{2}$. Selanjutnya, untuk banyak rumah tipe A dimisalkan dengan $x$ dan tipe $\mathrm{B}$ dimisalkan dengan $y$, juga diketahui bahwa paling banyak rumah yang akan dibangun untuk tipe $\mathrm{A}$ dan tipe $\mathrm{B}$ adalah 125, sedangkan keuntungan 
untuk rumah tipe $\mathrm{A}$ adalah 6.000.000/unit dan untuk rumah tipe $\mathrm{B}$ adalah 4.000.000/unit.

MODEL MATEMATIKA :
(i) $100 x+75 y \leqslant 10.000$
(ii) $x+y \leqslant 125$
(iii) $x \geq 0$
(iv) $y \geq 0$

Gambar 3. Model matematika subjek NPAS untuk soal nomor 1

P02 : Dari tabel masalah bagaimana caramu membuat model matematika?

NPAS02 : Sesuai dengan tabel masalah, diketahui bahwa rumah tipe $\mathrm{A}$ dan rumah tipe $\mathrm{B}$ memiliki luas tanah sebesar $100 \mathrm{~m}^{2}$ dan $75 \mathrm{~m}^{2}$ dengan ketersediaan luas tanah yang ada sebesar $10.000 \quad \mathrm{~m}^{2}$, sehingga diperoleh model matematikanya yaitu $100 x+75 y \leq 10.000$.

Selanjutnya, karena jumlah rumah yang dibangun paling banyak adalah 125 unit, jadi model matematikanya yaitu $x+y \leq 125$, dengan syarat $x \geq 0$ dan $y \geq 0$.

Hasil wawancara subjek NPAS (kategori sangat tinggi) terkait representasi gambar untuk soal nomor 1

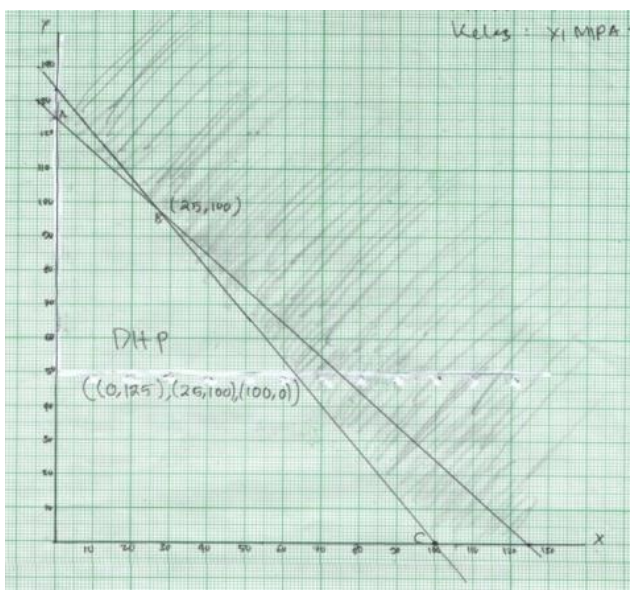

Gambar 4. Grafik penyelesaian subjek NAPS untuk soal nomor 1

P08 : Nah, apa yang kamu lakukan selanjutnya dari titik-titik yang diperoleh?

NPAS08 : Dari titik yang saya peroleh, saya memilih tiga pasangan titik untuk disubtitusikan ke dalam fungsi $6000.000 x+4000.000 y$ untuk mencari keuntungan maksimum, yaitu titik $(0,125),(25,100)$, dan $(100,0)$

P09 : Mengapa hanya tiga pasangan titik atau titik $(25,100),(0,125)$, dan
$(100,0) \quad$ yang dipilih untuk disubtitusikan ke dalam fungsi $6000.000 x+4000.000 y$ ?

NPAS09 : Karena ketiga pasangan titik tersebut termasuk pada daerah himpunan penyelesaian dari grafik yang digambarkan.

Hasil wawancara subjek NPAS (kategori sangat tinggi) terkait representasi verbal untuk soal nomor 1

yadi keuntungan maksimum yang diperollh yaitu $15000,000,000$

Gambar 5. Kesimpulan akhir subjek NPAS untuk soal nomor 1

P10 : Jadi dari ketiga pasangan titik yang telah disubtitusikan ke dalam fungsi tujuan $z(x, y)=6000.000 x+$ $4000.000 y$, berapakah keutungan maksimum yang diperoleh?

NPAS10 : Dari hasil subtitusi diperoleh nilai terbesarnya yaitu 600.000.000, sehingga keuntungan maksimum yang diperoleh adalah $\mathrm{Rp}$ 600.000.000,-

\section{(Soal Nomor 2)}

Hasil wawancara subjek NPAS (kategori sangat tinggi) terkait representasi gambar dan verbal untuk soal nomor 2

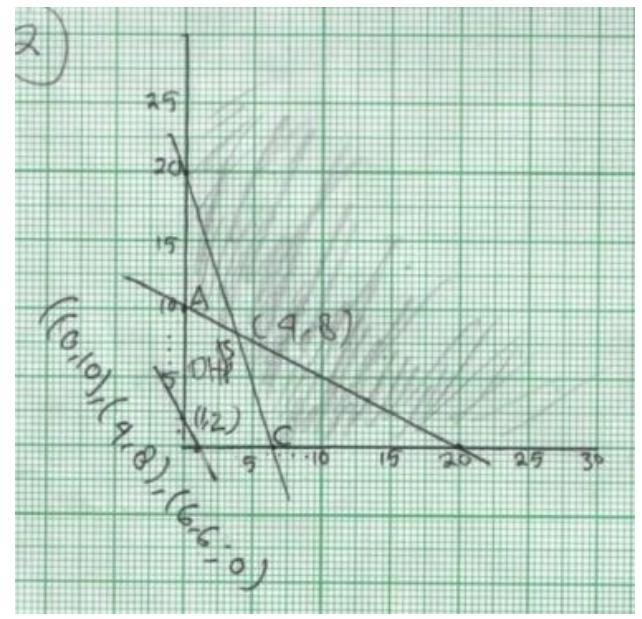

Gambar 6. Grafik penyelesaian subjek NAPS untuk soal nomor 2

P06 : Berdasarkan hasil pekerjaanmu, untuk menyelesaiakan permasalahan yang diberikan mengapa kamu hanya memilih tiga titik yaitu $(0,10),(4,8)$, dan $(6.6,0)$ dari sekian titik yang kamu peroleh dari proses penyelesaian sebelumnya? 
NPAS06 : Karena ketiga titik tersebut berada pada daerah himpunan penyelesaian pada grafik yang digambarkan

$$
\text { jaci titih } B(4,8)^{\prime} \text { mempaluan sitile maksimumura }
$$

Gambar 7. Kesimpulan akhir subjek NPAS untuk soal nomor 2

P07 : Nah berdasarkan grafik penyelesaianmu, terlihat bahwa ada garis baru dengan titik $x=1$ dan $y=$ 2 yang terletak pada daerah penyelesaian, mengapakah demikian?

NPAS07: Garis dengan titik $x=1$ dan $y=$ 2 merupakan garis selidik, saya namakan garis itu $2 x+y=k$. Untuk menentukan besar penghasilan maksimumnya, maka garis selidik tersebut saya geser ke titik $(4,8)$, karena titik $(4,8)$ merupakan titik maksimum pada daerah himpuan penyelesaian yang diperoleh. Selanjutnya, titik maksimum dengan $x=4$ dan $y=8$ tersebut disubtitusikan pada garis $2 x+y=k$, sehingga diperoleh penghasilan maksimumnya yaitu 16

\section{(Soal Nomor 3)}

Hasil wawancara subjek NPAS (kategori sangat tinggi) terkait representasi simbol untuk soal nomor 3

\begin{tabular}{|c|c|c|c|}
\hline JENIS TABLET & VITAMIN A & VITAMIN B & HAKGA \\
\hline TABLET I & 5 & 3 & 4.000 \\
\hline TABLET 2 & 10 & 1 & 8.000 \\
\hline PERLU & 20 & 5 & - \\
\hline \multicolumn{4}{|c|}{ MISALKAN: $\begin{aligned} x & =\text { BANRAK TABLET } 1 \\
y & =\text { BANYW TABLET } 2\end{aligned}$} \\
\hline \multicolumn{4}{|c|}{ MODEL MATUMATIKA: } \\
\hline \multicolumn{4}{|c|}{ (i) $5 x+10 y \geq 20$} \\
\hline \multicolumn{4}{|c|}{ (ii) $3 x+y \geq 5$} \\
\hline \multicolumn{4}{|l|}{ (iii) $x \geq 0$} \\
\hline (iv) $y \geq 0$ & & & \\
\hline
\end{tabular}

Gambar 8. Tabel masalah dan model matematika subjek NPAS untuk soal nomor 3

P02 : Lalu bagaimana kamu membuat model matematika dari masalah yang diberikan?

NPAS02 : Pertama saya membuat terlebih dahulu tabel masalah, kemudian dari tabel masalah saya buat model matematika. Dari tabel masalah diketahui tablet I mengandung 5 vitamin A dan tablet II mengandung 10 vitamin A. Keperluan untuk vitamin A yaitu 20 vitamin dalam sehari, sehinggga diperoleh model matematikanya yaitu $5 x+10 y \geq$ 20. Tablet I juga mengandung 3 vitamin B dan tablet II juga mengandung 1 vitamin B. Keperluan untuk vitamin B yaitu 5 vitamin dalam sehari, sehingga model matematika yang diperoleh yaitu $3 x+y \geq 5$, dengan syarat $x \geq$ 0 dan $y \geq 0$

Hasil wawancara subjek NPAS (kategori sangat tinggi) terkait representasi gambar untuk soal nomor 3

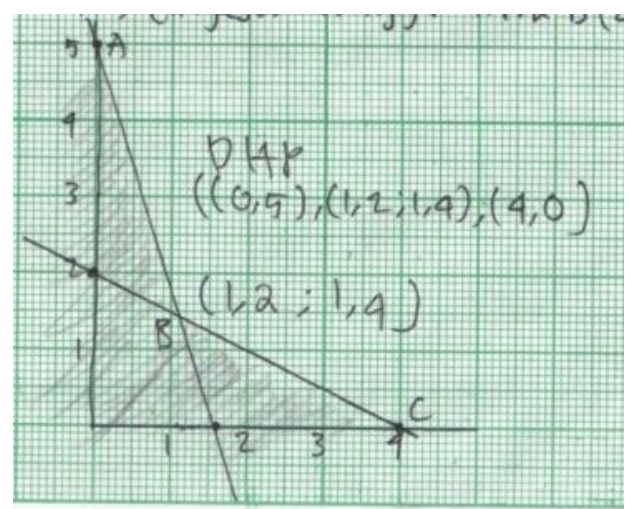

Gambar 9. Grafik Penyelesaian Subjek NAPS untuk soal nomor 3

P04 : Setelah selesai menentukan fungsi tujuan, bagaimana langkah selanjutnya yang kamu lakukan untuk menyelesaikan masalah yang diberikan pada soal nomor 3 ?

NPAS04 : Saya menentukan titik potong dengan sumbu $x$ dan sumbu $y$. Dengan memisalkan $x=0$ dan $y=0$, diperoleh nilai titik untuk model matematika $5 x+10 y=20$ adalah $(4,0)$ dan $(0,2)$, sedangkan untuk model matematika $3 x+y=5$ nilai titiknya adalah $(1.6,0)$ dan $(0,5)$. Titik-titik potong yang diperoleh digunakan untuk menggambar grafik penyelesaian. Selanjutnya, dari grafik yang digambarkan akan diperoleh titik perpotongan kedua garis.

P05 : Bagaimana caranya kamu menentukan nilai titik potong tersebut?

NPAS05 : Ditentukan dengan cara eliminasi dan subtitusi. Saya mengeliminasi variabel $y$ untuk memperoleh nilai variabel $x$. Eliminasi variabel y dilakukan dengan cara mengalikan 
model matematika $5 x+10 y=$ 20 dengan (1) dan model matematika $3 x+y=5$ dengan (10). Diperoleh nilai variabel $x$ yaitu 1.2. Lalu dari nilai variabel $x$ yang diperoleh, nilai variabel tersebut selanjutnya disubtitusikan ke model matematika $3 x+y=5$, sehingga diperoleh nilai variabel $y$ yaitu 1.4. Jadi, nilai titik perpotongan yang diperoleh dari cara eliminasi dan subtitusi adalah $(1.2,1.4)$.

Hasil wawancara subjek NPAS (kategori sangat tinggi) terkait representasi verbal untuk soal nomor 3

maka pengel uaran minimumnya adalah 16.000

Gambar 10. Kesimpulan akhir Subjek NPAS untuk soal nomor 3

P06 : Nah, selanjutnya untuk menentukan pengeluaran minimum, apa yang kamu lakukan dengan titik-titik yang diperoleh?

NPAS06 : Dari titik-titik yang diperoleh, titiktitik yang termasuk dalam daerah himpunan penyelesaian yang saya pilih untuk disubtitusikan ke fungsi tujuan. Titik-titik yang dipilih tersebut antara lain; $(0,5),(1.2,1.4)$, dan $(4,0)$ dan dari hasil subitusi ketiga nilai titik, diperoleh pengeluaran minimunya adalah Rp16.000,00

\section{Responden: DPRS}

(Soal Nomor 1)

Hasil wawancara subjek DPRS (kategori rendah) terkait representasi simbol untuk soal nomor 1

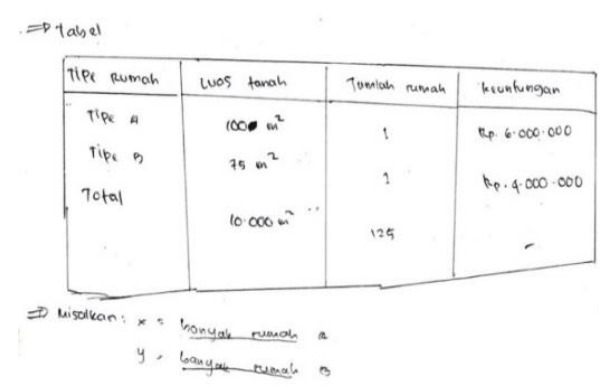

Gambar 11. Tabel masalah subjek DPRS untuk soal nomor 1

P02

: Dari apa yang kamu ketahui, bagaimana langkah kamu selanjutnya untuk menyelesaikan masalah yang diberikan?
DPRS02 : Selanjutnya saya membuat tabel masalah berdasarkan apa yang saya ketahui. Tabel masalah terdiri dari tipe rumah untuk kolom pertama, luas tanah untuk kolom kedua, jumlah rumah untuk kolom ketiga, dan keuntungan untuk kolom keempat, dengan memisalkan banyak rumah $\mathrm{A}$ dengan $x$ dan banyak rumah $\mathrm{B}$ dengan $y$.

P05 : Untuk menemukan solusi dari masalah yang diberikan, apa langkah selanjutnya yang kamu lakukan?

DPRS05 : Saya menentukan titik potong dengan sumbu $x$ dan sumbu $y$, untuk model matematika $100 x+75 y=10.000$, diperoleh nilai titik-titik potongnya yaitu $(100,0)$ dan $(0,133.3)$, misal dengan sumbu $x$ maka $y=0$, sehingga diperoleh $100 x=10.000$ atau $x=\frac{10.000}{100}=100$ dan misal dengan sumbu $y$ maka $x=0$, sehingga diperoleh $75 y=10.000$ atau $\frac{10.000}{75}=133.3$, kalau untuk model matematika $x+y=125$, diperoleh nilai titik-titik potongnya yaitu $(125,0)$ dan $(0,125)$. Selanjutnya, dari titik-titik potong dengan sumbu $x$ dan sumbu $y$ yang telah diperoleh, saya kemudian menggambar grafik penyelesaian. Dan dari grafik penyelesaian di dapatkan juga titik potong dari kedua garis

Hasil wawancara subjek DPRS (kategori rendah) terkait representasi gambar untuk soal nomor 1

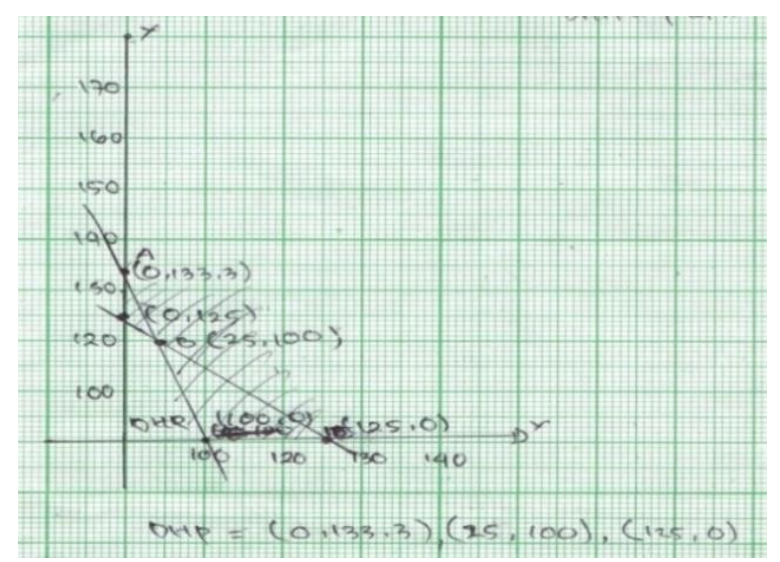

Gambar 12. Grafik penyelesaian subjek DPRS untuk soal nomor 1

P06

$$
\begin{aligned}
& \text { Bagaimana caranya kamu } \\
& \text { menentukan titik potong yang } \\
& \text { diperoleh dari kedua garis tersebut? }
\end{aligned}
$$

DPRS06 : Saya menentukannya dengan cara eliminasi dan subtitusi, saya 
mengeliminasi variabel $y$ untuk memperoleh nilai variabel $x$. Eliminasi variabel $y$ dilakukan dengan cara mengalikan model matematika $100 x+75 y=10.000$ dengan (1) dan model matematika $x+y=125$ dengan (75), sehingga dari eliminasi tersebut diperoleh nilai varibel $x$ adalah 25. Dari nilai variabel $x$ yang diperoleh, nilai variabel tersebut kemudian disubtitusikan ke model matematika $x+y=125, \quad$ sehingga diperoleh nilai variabel $y$ adalah 100 . Jadi, nilai titik potong yang diperoleh dari proses eliminasi dan subtitusi adalah $(25,100)$

Hasil wawancara subjek DPRS (kategori rendah) terkait representasi verbal untuk soal nomor 1

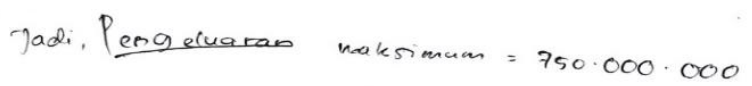

Gambar 13. Kesimpulan akhir subjek DPRS untuk soal nomor 1

P07

: Dari sekian titik yang telah kamu peroleh, apa langkah selanjutnya yang kamu lakukan untuk menemukan solusi akhir dari masalah yang diberikan?

DPRS07 : Saya menentukan uji titik pojok terhadap fungsi tujuan dengan mensubtitusikan tiga nilai titik yang saya pilih. Kemudian dari uji titik pojok diperoleh keuntungan maksimumnya adalah Rp750.000.000,00.

\section{(Soal Nomor 2)}

Hasil wawancara subjek DPRS (kategori rendah) terkait representasi gambar dan verbal untuk soal nomor 2

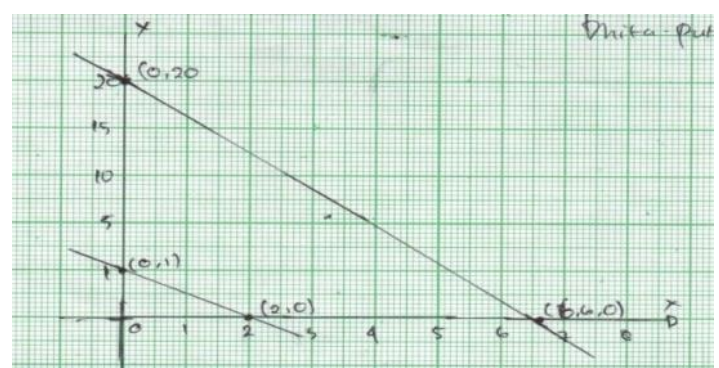

Gambar 14. Grafik Penyelesaian Subjek DPRS untuk soal nomor 2

: Apakah penentuan titik potong dengan sumbu $x$ dan sumbu $y$ dari model matematika membantumu menemukan solusi dari masalah yang diberikan?

DPRS02 : Iya. Tetapi saya terburu-buru dalam menentukan titik potong dan juga menggambar grafik penyelesaian pada pengerjaan saya, jadi saya tidak dapat menemukan solusi dari masalah pada soal nomor 2

\section{(Soal Nomor 3)}

Hasil wawancara subjek DPRS (kategori rendah) terkait representasi simbol untuk soal nomor 3

$$
\begin{aligned}
& \begin{array}{l}
3 . \rightarrow \text { Tanel } \\
\begin{array}{|l|c|c|c|}
\hline \text { Jenis tablet } & \text { vitamin A } & \text { vitamin B } & \text { Harga } \\
\text { Tablet 1 } & 5 & 3 & \text { R. } 4.000,00 \\
\text { Tablet i } & 10 & 1 & \text { R. } 3.000 .00 \\
\hline \text { Jumiah Tablet } & 20 & 5 & - \\
\hline
\end{array}
\end{array} \\
& \Rightarrow \text { Misalkan: } x \text { : Coanyak tablet If } \\
& y \text {. banyak lablet if } \\
& \Rightarrow \text { Model matematika } \\
& \text { (i) } 5 x+10 y \geqslant 20 \\
& \text { (ii) } 3 x+y \geq 5 \\
& \text { (iii) } x \geq 0 \\
& \text { (iv) } y \geq 0
\end{aligned}
$$

Gambar 15. Tabel masalah dan model matematika subjek DPRS untuk soal nomor 3

P02 : Apa yang harus ditentukan dari masalah pada soal yang diberikan?

DPRS02 : Diminta untuk menentukan pengeluaran minimum dari pembelian tablet

P03 : Nah, bagaimana caramu menentukan pengeluaran minimum dari pembelian tablet?

DPRS03 : Pertama, saya membuat tabel masalah dari soal nomor 3, kemudian membuat model matematikanya

P04 : Setelah itu, langkah apakah yang kamu lakukan untuk memperoleh model matematika dari masalah yang diberikan?

DPRS04 : Membuat pemisalan, dengan memisalkan banyak tablet I itu $x$ dan banyak tablet II itu $y$. Kemudian sesuai dengan tabel masalah diketahui tablet I mengandung 5 vitamin A dan tablet II mengadung 10 vitamin A, keperluan vitamin A dalam sehari yaitu 20 vitamin, sehinggga diperoleh model matematikanya yaitu $5 x+$ 
$10 y \geq 20$. Tablet I juga mengandung 3 vitamin $\mathrm{B}$ dan tablet II mengandung 1 vitamin $\mathrm{B}$, keperluan vitamin B dalam sehari yaitu 5 vitamin, jadi diperoleh model matematikanya yaitu $3 x+y \geq 5$, dengan syarat $x \geq 0$ dan $y \geq 0$. Dari tabel masalah juga saya dapat menentukan fungsi tujuannya yaitu $z(x, y)=4.000 x+8.000 y$

P06 : Bagaimana caranya kamu mencari titik-titik potong dengan sumbu $x$ dan juga sumbu $y$ ?

DPRS06 : Saya memisalkan nilai variabel $x=$ 0 dan nilai variabel $y=0$. misal $y=$ 0 maka $5 x=20$ atau $=\frac{20}{5}=4$, jadi nilai titiknya yaitu $(4,0)$, kemudian misal $x=0$ maka $10 y=20$ dan $x=$ $\frac{20}{10}=2$, jadi nilai titiknya $(2,0)$. Sedangkan untuk model matematika $3 x+y=5$, misal $y=0$ maka $x=\frac{5}{3}$ $=1.6$, jadi nilai titiknya $(1.6,0)$, kemudian misal $x=0$ maka $y=5$, jadi nilai titiknya $(0,5)$

Hasil wawancara subjek DPRS (kategori rendah) terkait representasi gambar untuk soal nomor 3

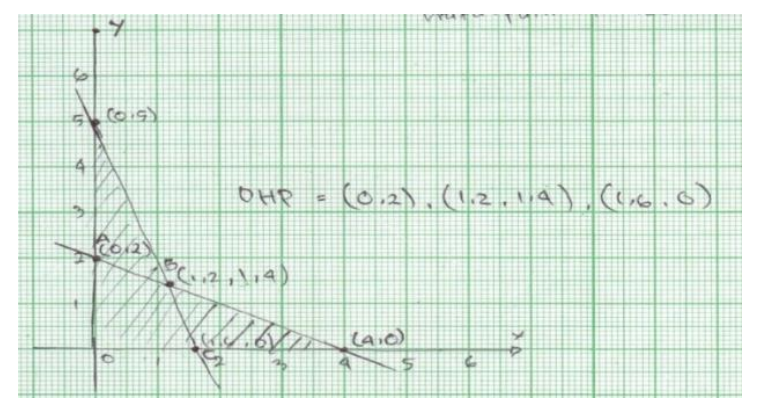

Gambar 16. Grafik penyelesaian subjek DPRS untuk soal nomor 3

P07 : Setelah kamu memperoleh titik-titik potong dengan sumbu $x$ dan sumbu $y$, apa yang selanjutnya kamu lakukan dengan titik-titik potong sumbu tersebut?

DPRS07 : Saya menggambarkannya ke dalam bentuk grafik penyelesaian. Kemudian dari grafik tersebut saya pula mencari nilai titik perpotongan dua garis.

P08 : Bagaimana caranya kamu mencari nilai titik perpotongannya?

DPRS08 : Saya mencari nilai titik potongnya dengan menggunakan eliminasi dan subtitusi. Saya mengeliminasi variabel y untuk mencari nilai variabel $x$ dengan cara mengalikan model matematika $5 x+10 y=20$ dengan (1) dan model matematika $3 x+y=5$ dengan (10). Dari eliminasi tersebut diperoleh nilai varibel $x$ adalah 1.2 Dari nilai variabel $x$ yang diperoleh, nilai variabel tersebut disubtitusikan ke model matematika $5 x+10 y=20$, sehingga diperoleh nilai variabel $y$ adalah 1.4. Jadi nilai titik perpotongan yang diperoleh dari proses eliminasi dan subtitusi adalah $(1.2,1.4)$

Hasil wawancara subjek DPRS (kategori rendah) terkait representasi verbal untuk soal nomor 3

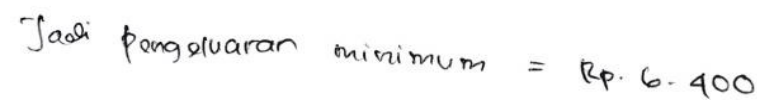

Gambar 17. Kesimpulan akhir subjek DPRS untuk soal nomor 3

P09 : Dari sekian titik yang telah kamu peroleh, apa langkah selanjutnya yang kamu lakukan untuk menemukan pengeluaran minimum dari masalah yang diberikan?

DPRS09 : Saya menentukan uji titik pojok terhadap fungsi tujuan dengan mensubtitusikan tiga nilai titik yang saya pilih. Kemudian dari uji titik pojok diperoleh pengeluaran minimumnya adalah Rp6.400,00.

\section{Responden: NPS \\ (Soal Nomor 1)}

Hasil wawancara subjek NPS (kategori sangat rendah) terkait representasi simbol untuk soal nomor 1

\begin{tabular}{|l|l|c|c|}
\hline TIPE RUMAH & LUAS TANAH & EANYAK RUMAH & KEUNTUNGAN \\
\hline TIPE A & $100 \mathrm{~m}^{2}$ & $x$ & 6.000 .000 \\
\hline TIPE B & $75 \mathrm{~m}^{2}$ & $y$ & 9.000 .000 \\
\hline TERSEDIA & $10.000 \mathrm{~m}^{2}$ & 125 & - \\
\hline Micalkan: $x=$ Banyak numah tipe A \\
$y=$ Banyak rumah tipe B
\end{tabular}

Gambar 18. Tabel masalah subjek NPS untuk soal nomor 1

P01 : Bagaimana caramu membuat tabel masalah dari masalah yang diberikan?

NPS01 : Sesuai dengan masalah yang diberikan, diketahui jenis rumah ada rumah tipe A dan juga rumah tipe $B$, saya memisalkan rumah tipe A sebagai $x$ dan rumah tipe B sebagai $y$, kemudian 
diketahui pula luas tanah, jumlah rumah dan keuntungan.

$$
\begin{aligned}
& \text { Model matematika: } \\
& \text { (I) }=100 x+75 y \leq 6.000 .000 \\
& (I I)=1 x+1.000 .000 . \\
& (\text { III }=x \geq 0 \\
& \text { (IV) }=y \geq 0
\end{aligned}
$$

Gambar 19. Model matematika subjek NPS untuk soal nomor 1

P02

: Nah, bagaimana caramu membuat model matematika berdasarkan tabel masalah yang telah kamu peroleh sebelumnya?

NPS02 : Dari tabel masalah diketahui bahwa rumah tipe $\mathrm{A}$ dan rumah tipe $\mathrm{B}$ memiliki luas tanah sebesar $100 \mathrm{~m}^{2}$ dan $75 \mathrm{~m}^{2}$ dengan keuntungan rumah tipe A adalah Rp6000.000,00, sehingga diperoleh model matematikanya yaitu $100 x+75 y \leq$ 6.000.000. Selanjutnya, karena jumlah rumah tipe $\mathrm{A}$ dan tipe $\mathrm{B}$ adalah 1 dengan keuntungan rumah tipe $B$ adalah Rp4.000.000,00, sehingga model matematikanya yaitu $1 x+$ $1 y \leq 4.000 .000$, dengan syarat $x \geq$ 0 dan $y \geq 0$.

Hasil wawancara subjek NPS (kategori sangat rendah) terkait representasi gambar untuk soal nomor 1

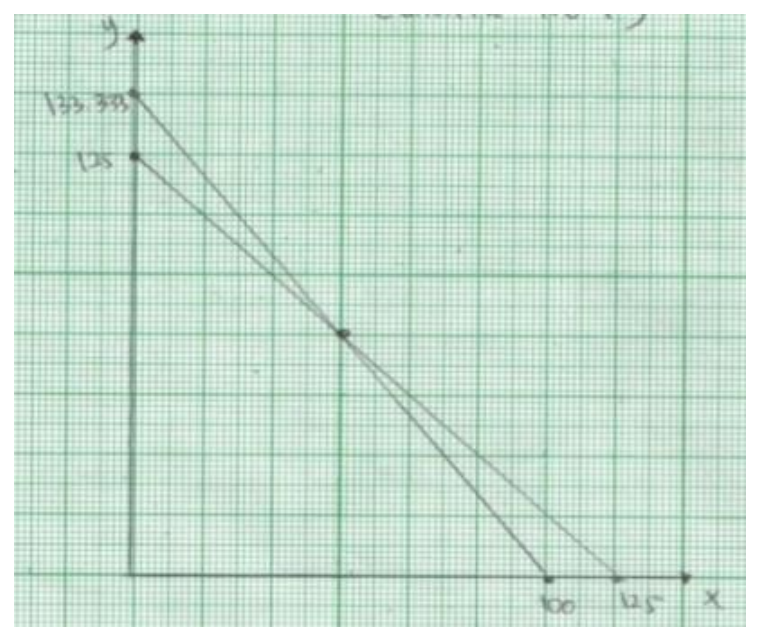

Gambar 20. Grafik penyelesaian subjek NPS untuk soal nomor 1

P04 : Selanjutnya, apakah yang kamu lakukan untuk menyelesaikan permasalahan yang diberikan?

NPS04 : Saya menggambar grafik penyelesaian dan menentukan titk potong dari kedua garis dengan cara subtitusi dan eliminasi. Kemudian diperoleh nilai titik $x=1.75$ dan $y=$

2.3 untuk model matematika $100 x+$ $75 y=175, x=250$ dan $y=250$ untuk model matematika $x+y=$ 150

\section{(Soal Nomor 2)}

$\mathrm{P} 01$

NPS01 : Sesuai dengan soal, pertama saya membuat tabel masalah, kemudian menuliskan model matematika dan juga fungsi tujuan yang sudah diketahui di soal.

P02 : Setelah itu?

NPS02 : Saya menetukan titik potong dengan sumbu $\mathrm{x}$ dan sumbu $\mathrm{y}$, dengan memisalkan $\quad x=0$ dan $\quad y=0$. Diperoleh $(20,0)$ dan $(0,100)$ untuk model matematika $10 x+2 y \leq 200$ juga $(6.6,0)$ dan $(0,20)$ untuk model matematika $\quad 15 x+5 y \leq 200$. Selanjutya saya buat subtitusi dan eliminasi, tetapi karena keterlambatan waktu jadinya soalnya tidak dapat diselesaikan

\section{(Soal Nomor 3)}

Hasil wawancara subjek NPS (kategori sangat rendah) terkait representasi simbol untuk soal nomor 3

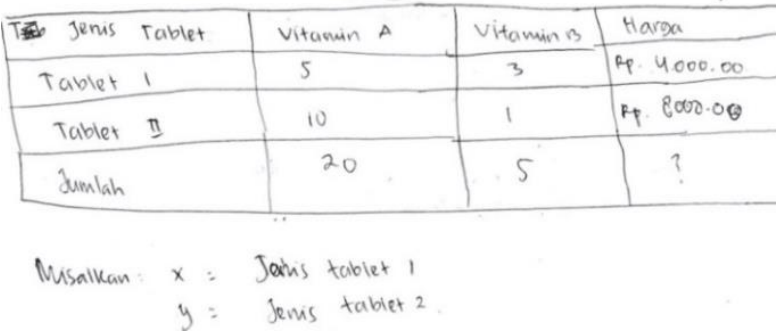

Gambar 21. Tabel masalah subjek NPS untuk soal nomor 3

P01 : Bagaimana caramu membuat tabel masalah dari masalah yang diberikan?

NPS01 : Sesuai dengan masalah yang diberikan, diketahui jenis tablet ada tablet jenis I dan jenis II, saya misalkan tablet jenis I sebagai sebagai $x$ dan tablet jenis II sebagai $y$, kemudian diketahui pula tablet I mengandung 5 vitamin $\mathrm{A}$, tablet II mengandung 10 vitamin $\mathrm{A}$, dengan jumlah vitamin A itu 20. Sedangkan tablet I mengandung 3 vitamin B dan tablet II mengandung 1 vitamin $B$, dengan jumlah vitamin B itu 5. Harga tablet I Rp4.000,00 dan harga tablet II $\mathrm{Rp} 8000,00$. 


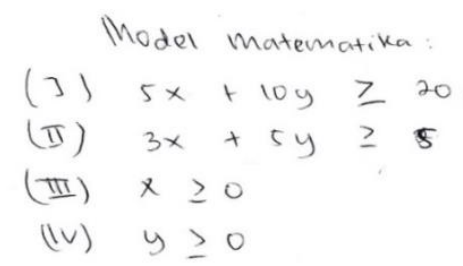

Gambar 22. Model matematika subjek NPS untuk soal nomor 3

P02

NPS02 : Karena tablet I mengandung 5 vitamin A, tablet II mengandung 10 vitamin A, dengan jumlah vitamin A itu 20, jadi model matematikanya yaitu $5 x+$ $10 y \geq 20$. Kemudian tablet I mengandung 3 vitamin B dan tablet II mengandung 1 vitamin $\mathrm{B}$, dengan jumlah vitamin B itu 5, jadi model matematikanya yaitu $3 x+5 y \geq$ 5, dengan syarat $x \geq 0$ dan $y \geq 0$

Berdasarkan hasil penelitian, diperoleh nilai rata-rata kemampuan represenatsi matematis keseluruhan peserta didik di kelas XI MIPA 4 SMA Negeri 3 Ambon pada materi program linear adalah 17.61, sedangkan nilai rata-rata per representasi matematisnya adalah 35.65 untuk nilai rata-rata representasi simbol, 11.42 untuk nilai rata-rata representasi gambar, dan 3.70 untuk nilai rata-rata representasi verbal. Berdasarkan nilai rata-rata representasi matematis keseluruhan dan nilai rata-rata per representasi matematis, maka dapat disimpulkan bahwa peserta didik belum dapat memenuhi indikator kemampuan representasi gambar dan representasi verbal karena nilai rata-rata kedua indikator tersebut berada dibawah nilai rata-rata keseluruhan. Selain itu, sesuai dengan Tabel 1 disimpulkan bahwa persentase terbesar hasil tes kemampuan representasi matematis peserta didik berada pada kategori sangat rendah. Dari hasil pekerjaan peserta didik, ditemukan adanya peserta didik yang dapat mengerjakan soal dengan benar, ada peserta didik yang salah dalam mengerjakan soal, dan adapula peserta didik yang tidak dapat mengerjakan soal hingga selesai. Hal ini disebabkan karena peserta didik belum sepenuhnya menggunakan kemampuan representasi matematisnya dengan benar.

Berdasarkan analisis data dan wawancara, maka kemampuan representasi ketiga subjek dapat diketahui bahwa subjek NPAS dengan kategori sangat tinggi dapat memenuhi tiga indikator kemampuan representasi matematis peserta didik, meliputi representasi simbol, representasi gambar, dan representasi verbal. Ini berarti subjek NPAS dapat menggunakan kemampuan representasi simbol, representasi gambar, dan representasi verbal dalam menyelesaikan masalah program linear yang diberikan. Jika semakin banyak representasi yang muncul, maka akan semakin memudahkan peserta didik dalam memilih cara yang paling cepat dan tepat untuk menyelesaikan suatu masalah (Dahlan \& Juandi, 2011), sehingga dalam menyelesaikan suatu masalah yang lain, subjek NPAS dapat dengan mudah memilih cara yang paling cepat dan tepat dalam menyelesaikan masalah tersebut. Sedangkan subjek DPRS dengan kategori rendah dapat memenuhi indikator kemampuan representasi simbol, tetapi cenderung kurang dalam memenuhi indikator kemampuan representasi gambar dan representasi verbal. Berbeda dengan subjek NPAS dan DPRS, subjek NPS dengan kategori sangat rendah belum dapat memenuhi ketiga indikator kemampuan representasi matematis.

Berdasarkan kajian bahasan di atas disimpulkan bahwa ketiga subjek yang diwawancarai lebih cenderung memenuhi indikator kemampuan representasi simbol dibandingkan indikator kemampuan representasi gambar dan verbal. Hal ini sesuai dengan hasil penelitian yang dilakukan oleh Triono (2017) yang menemukan bahwa kemampuan representasi matematis peserta didik pada indikator representasi simbol jauh lebih baik dari indikator representasi gambar dan representasi verbal.

\section{Kesimpulan}

Nilai rata-rata kemampuan representasi matematis keseluruhan peserta didik adalah 17.61. Persentase terbesar hasil tes peserta didik berada pada kategori sangat rendah. Kemampuan representasi matematis peserta didik pada representasi simbol lebih tinggi dari representasi gambar dan representasi verbal. Hal ini dapat dilihat pada nilai rata-rata representasi simbol, gambar, dan verbal yang diperoleh, yakni rata-rata kemampuan representasi simbol (symbolic representation) peserta didik adalah 35.65 , ratarata kemampuan representasi gambar (pictorial representation) peserta didik adalah 11.42 , dan rata-rata kemampuan representasi verbal (verbal representation) peserta didik adalah 3.70 . Sedangkan dari ketiga subjek yang diwawancarai ditemukan bahwa subjek cenderung memenuhi indikator kemampuan representasi simbol dibandingkan indikator kemampuan representasi gambar dan representasi verbal. 
Kemampuan representasi tampak pada tujuan pemecahan masalah, komunikasi matematika, dan koneksi matematis karena untuk menyelesaikan masalah matematis, diperlukan kemampuan untuk membuat model matematika dan menafsirkan solusinya serta mengkoneksikan masalah kontekstual dengan topik-topik dalam matematika. Selain itu, kemampuan representasi matematis juga berhubungan dengan kemampuan dasar dalam berpikir matematis, memahami konsep, dan menggunakan konsep-konsep tersebut dalam memecahkan masalah yang dihadapi.

\section{Daftar Pustaka}

Castellanos, J. L. V., Castro, E., \& Gutiérrez, J. (2009). Representations in problem solving: A case study with optimization problems. Electronic Journal of Research in Educational Psychology, 7(17), 279-308.

Dahlan, J. A., \& Juandi, D. (2011). Analisis Representasi Matematik Siswa Sekolah Dasar Dalam Penyelesaian Masalah Matematika Kontekstual. Jurnal Pengajaran Matematika Dan Ilmu Pengetahuan Alam, 16(1), 128. https://doi.org/10.18269/jpmipa.v16i1.273

Emzir. (2014). Metodologi Penelitian Kualitatif. Rajawali Pers.

Fikri, F. N., Mardiayan, \& Kuswardi, Y. (2017). Analisis Kemampuan Berpikir Kritis Dalam Pemecahan Masalah Matematika Berdasarkan Langkah-Langkah Facione Pada Materi Program Linear Ditinjau Dari Minat Belajar Siswa Kelas XI MAN Purwodadi. Jurnal Pendidikan Matematika Dan Matematika (JPMM), 1(2), 56. https://doi.org/10.4135/9781412950589.n774

Hadi, S., \& Novaliyosi. (2019). TIMSS Indonesia (Trends in International Mathematics and Science Study). Prosiding Seminar Nasional \& Call For Papers Program Studi Magister Pendidikan Matematika Universitas Siliwangi, 562-569.

Handayani, H. (2015). Pemanfaatan Benda-Benda. I, $142-149$.

IEA. (2012). TIMSS 2011 International Result in Mathematics. http://timss.bc.edu/timss2011/downloads/T11_I R_M_Chapter1.pdf
Peraturan Menteri Pendidikan Dan Kebudayaan Republik Indonesia No. 21 Tahun 2016 tentang Standar Isi Pendidikan Dasar dan Menengah, (2016).

Izah, dkk. (2018). Analisis Proses Berpikir Siswa SMA dalam Menyelesaikan Soal Cerita pada Materi Program Linear ditinjau dari Kecerdasan Emosional. Seminar Nasional Penelitian dan Pengabdian Masyarakat, h. 187-195.

Keller, B. A., Hart, E. W., \& Martin, W. G. (2001). Illuminating NCTM's Principles and Standards for School Mathematics. School Science and Mathematics, 101(6), 292-304. https://doi.org/10.1111/j.19498594.2001.tb17960.x

Muhamad, N. (2016). Pengaruh Metode Discovery Learning untuk Meningkatkan Representasi Matematis dan Percaya Diri Siswa. Jurnal Pendidikan Universitas Garut, 09(01), 9-22.

OECD. (2015). PISA 2015 Result in Focus-student performance in mathematics, reading and science. https://www.oecd.org/pisa/pisa-2015results-in-focus-pdf

Ratumanan, T. G \& Laurens, T. (2015). Penilaian Hasil Belajar pada Tingkat Satuan Pendidikan. Pensil Komunika.

Mandur, dkk. (2013). Kontribusi Kemampuan Koneksi, Kemampuan Representasi, Dan Disposisi Matematis Terhadap Prestasi Belajar Matematika Siswa Sma Swasta di Kabupaten Manggarai. e-Journal Program

Pascasarjana Universitas Pendidikan Ganesha Program Studi Matematika. Vol 2

Sukino. (2013). Three in One Matematika IPA untuk SMA/MA Kelas XII (M. Darmanto (ed.)). Erlangga.

Thoriqul, M., \& Mustangin. (2020). Program Studi Pendidikan Matematika FKIP Universitas Pasir Pengaraian. Jp3, 5(2), 67-74.

Tohir, M. (2019). Hasil PISA Indonesia Tahun 2018 Turun Dibanding Tahun 2015 (Indonesia's PISA Results in 2018 are Lower than 2015). 20182019.

Triono, A. (2017). ANALISIS KEMAMPUAN REPRESENTASI MATEMATIS SISWA KELAS VIII SMP NEGERI 3 TANGERANG SELATAN Skripsi. 107.

Zakkia, A., Isnarto, Asih, T. S. N., \& Wardono. (2019). Kemampuan Literasi Matematika Siswa pada Pembelajaran Brain Based Learning. PRISMA, Prosiding Seminar Nasional Matematika, 2, 3439. 